\title{
Evidence of validity and factorial invariance of the Sternberg Love Scale Brief Spanish Version
}

\author{
José Ventura-León; Tomas Caycho-Rodríguez; Stefani Jara-Avalos; \\ Jeaniret Yañez; Kelly Icochea; Nikolai Rodas
}

How to cite this article:

Ventura-León, J., Caycho-Rodríguez, T., Jara-Avalos, S., Yañez, J., Icochea, K. \& Rodas, N. (2020). Evidence of validity and factorial invariance of the Sternberg Love Scale Brief Spanish Version Acta Colombiana de Psicología, 23(2), 8697. http://www.doi.org/10.14718/ACP.2020.23.2.5

Recibido, marzo 01/2019; Concepto de evaluación, junio 15/2019; Aceptado, febrero 11/2020

José Ventura-León*

Universidad Privada del Norte, Lima, Perú

ORCID: https://orcid.org/0000-0003-2996-4244

Tomas Caycho-Rodríguez

Universidad Privada del Norte, Lima, Perú

ORCID: https://orcid.org/0000-0002-5349-7570

Stefani Jara-Avalos

Universidad Privada del Norte, Lima, Perú

ORCID: https://orcid.org/0000-0002-9021-7355

Jeaniret Yañez

Universidad Privada del Norte, Lima, Perú

ORCID: https://orcid.org/0000-0002-2931-7883

Kelly Icochea

Universidad Privada del Norte, Lima, Perú

ORCID: https://orcid.org/0000-0002-4735-1364

Nikolai Rodas

Universidad César Vallejo, Lima, Perú

ORCID: https://orcid.org/0000-0001-6740-3099

\begin{abstract}
This study aims to adapt, provide evidence of validity, analyze the invariance across gender, and estimate the reliability of the reduced version of the Sternberg's Triangular Love Scale (STLS-R). The sample size comprises 988 Peruvians (748 females and 240 males), who had been in a relationship for at least one month, and whose ages ranged from 16 to 54 years old $(\mathrm{M}=21.29 ; \mathrm{SD}=3.91)$. Before the statistical analysis, the semantic equivalence was tested through the translation-back translation method. The results indicate that the three-dimensional STLS-R model present satisfactory goodness-of-fit in the data $\left(\chi^{2}(87)=177.14 ; \chi 2 / \mathrm{df}=2.04 ; \mathrm{CFI}=.99 ; \mathrm{RMSEA}=.03[.02, .04] ; \mathrm{SRMR}=.03\right)$ which is invariant with respect to gender, and show acceptable reliability regarding intimacy $(\omega=.91)$, commitment $(\omega=.93)$ and passion $(\omega=.86)$. The overall results offer sufficient valid evidence and suggest that the scale can be used in further studies. However, its effectiveness should still be tested in different regions of Peru.
\end{abstract}

Keywords: validity, reliability, invariance, love, Sternberg.

\section{Evidencia de validez e invarianza factorial de la Escala Breve de Amor de Sternberg}

\begin{abstract}
Resumen
El presente estudio tuvo como objetivo adaptar, brindar evidencias de validez, revisar la invarianza según el sexo y estimar la fiabilidad de la Escala Triangular de Amor de Sternberg en una versión reducida (ETAS-R). Para esto, participaron 988 personas - 748 mujeres y 240 varones_- con edades que oscilaron entre los 16 y los 54 años $(M=21.29 ; D E=3.91)$, con mínimo un mes en una relación de pareja. Previo al análisis estadístico se comprobó la equivalencia semántica del instrumento mediante la traducción inversa. Los resultados revelan que el modelo tridimensional de la ETAS-R presenta buenas
\end{abstract}

Av. Alfredo Mendiola 6062, Los Olivos 15306, Tel.: (511) 6143311. jose.ventura@upn.pe 
bondades de ajuste en los datos $(\chi 2(87)=177.14 ; \chi 2 / \mathrm{gl}=2.04 ; \mathrm{CFI}=.99 ; \mathrm{RMSEA}=.03[.02, .04] ;$ SRMR $=.03)$, que la prueba es invariante según el sexo, y que su fiabilidad es buena tanto en intimidad $(\omega=.91)$ como en compromiso $(\omega=.93)$ y pasión $(\omega=.86)$. En conclusión, la escala muestra adecuadas evidencias de validez y puede ser utilizada para futuros estudios. Pese a ello, aún debe comprobarse su efectividad en diferentes regiones de Perú.

Palabras clave: validez, fiabilidad, invarianza, amor, Sternberg.

\section{Introduction}

Love is a universal phenomenon (Al-Krenawi \& Jackson, 2014), very important in the context of close relationships (Graham, 2011), which has been subject of considerable attention and discussion over the past years (Wan Shahrazad, Hoesni \& Chong, 2012). Despite this fact, to date, there still is a lack of a unified scientific approach that enables exhaustive studies concerning this intriguing phenomenon (Pilishvili \& Koyanongo, 2016).

From the psychological perspective, love was initially conceived as an effort to achieve the ego-ideal (Freud, 1922) as well as a need that causes adversity in relationships that if not satisfied, might hamper the self-realization of individuals (Fromm, 2004; Maslow, 1991). On the other hand, some authors refer to love as a deep sense of affection towards someone else (Vera, 2017). Nevertheless, in some cases, this definition might disregard important cognitive, affective and behavioral processes involved (Hatfield, Rapson, \& Martel, 2007). There are other definitions of love that are subject to one's interpretation and to the social circumstances of individuals (Le Breton, 1999), as can be observed within the context of the concept Amae practiced in Japanese descendants in Bolivia (Sakuray \& Akemi, 2014). In addition, expressions of love can vary from one society to another. For instance, companionate love, which stressed commitment, is typical in collectivist societies while passionate love is highly regarded in individualistic societies (Kim \& Hatfield, 2004). On the other hand, some authors argue that there is a transcultural impact in the conceptualization of love due to the influence of cultural globalization and international media such as television, films, and Internet (Vera, 2017).

In fact, since the early 1970s, on the basis of the seminal works of Rubin (1970), several theoretical models have been developed to understand love from a psychological perspective (Sternberg \& Barnes, 1988). In such a sense, depending on the theoretical perspective, love can be considered a feeling (Precht, 2012), an act of will (Fromm, 2004; Scott, 1997), a choice (Singer, 2006) or an event that goes beyond the partnership framework (Ortega \& Gasset, 1939/2005).

Naturally, the variety of definitions (Hatfield, Bensman, \& Rapson, 2012), creates different ways of classifying love (Neto \& Conceição Pinto, 2015) which develop in the biocultural, sociocultural, individual, evaluative and behavioral fields (Díaz-Loving \& Sánchez, 2002). In this sense, Lee (1977) has differentiated between six types of love: Eros (passionate love), Ludus (ludic love), Storge (friendship love), wherein combinations of these three can result into the so-called Mania (possessive love), Pragma (pragmatic love), and Agape (selfless love). Likewise, the existence of passionate and companionate love (Hatfield \& Rapson, 1996), corporal, sentimental and existential love (Frankl, 1997), affective, cognitive and interpersonal love (De Zubiría, 2002), as well as passion, intimacy and commitment (Sternberg 1986) have also been mentioned. This shows that the different perspectives concerning love have varied considerably with diversity of orientations and psychological schools (psychoanalytic, cognitivism, behaviorism, humanistic, among others). As a consequence, to date, there is no universally agreed upon general definition of love (Levin \& Kaplan, 2010).

For some authors (Mazadiego \& Norberto, 2011), the widely theoretical model currently used is the Sternberg's triangular love theory (Sternberg, 1986). This is because of its fairly general capability to comprehend the love experiences between individuals of different societies (Gao, 2001). Nonetheless, this model has not been studied thoroughly in the Peruvian context, due to the fact that there is only one validation of the long version of the scale of love in Peruvian youth and adults.

Sternberg's model proposes that love can be inferred as a combination of three components: intimacy, passion, and commitment (Sternberg, 1986). Intimacy is defined as a degree of trust, nearness and connection in a relationship. This component relies upon emotions that comprise a warm experience in a relationship (Diessner, Frost \& Smith, 2004). Passion is the force that leads to romance i.e., physical or sexual attraction. Lastly, commitment implies a decision to love and being loved as well as the willingness to maintain love over time (Sternberg, 1986).

The interaction of the mentioned components give rise to seven other forms of love which are: liking (only intimacy is experienced), infatuated love (only the passion component is present), empty love (the commitment component dominates), romantic love (combination of intimacy and passion), companionate love (blend between intimacy and 
commitment), fatuous love (interrelation between passion and commitment), consummate love (a combination of the three components). Accordingly, the lack of love is understood as a state where the three components are absent (Heinrich, Albrecht \& Bauer, 2012).

Based on this theoretical model, the Sternberg's triangular love scale (STLS; Sternberg, 1997), that measures the components of intimacy, passion and commitment, was constructed. Originally, the 36-item STLS was validated in a sample of 84 American adults. There, the participants responded six times each scale, describing the love they felt toward their mothers, fathers, sisters, friends of the same sex, persons whom they loved and finally, an ideal lover. The psychometric analysis of the first STLS version indicated the presence of alpha coefficients greater than 0.80 , with the commitment component slightly lower $(\alpha=0.79)$. Also, high correlations among the three components were observed, while not all items presented high saturations in the initially expected components, which caused problems in the factorial analysis of the STLS. In a second study, Sternberg (1997) replaced the problematic items and included three items in each component, giving rise to a second 45 -item STLS version. This version showed alpha coefficients greater than 0.90 and correlations between the components of 0.71 and 0.73 .

In fact, several psychometric studies around the world have reported evidence of validity and reliability similar to the one originally reported by Sternberg (1997). For instance, in Latin America, STLS has been validated in some countries including, Mexico (Mazadiego \& Norberto, 2011), Brazil (Cassepp-Borges \& Pasquali, 2012; Cassepp-Borges \& Teodoro, 2007; Hernández, 1999) and Peru (VenturaLeón \& Caycho-Rodríguez, 2016) although recently it has been suggested that the structure of the 45-item STLS is very complex when compared with other reduced versions STLS-R (Evangelho, 2016). In fact, many items of the original version load in more than one factor, so when they are removed it is possible to keep a fair level of precision in STLS-R with Cronbach's alpha index above .85 (CasseppBorges \& Pasquali, 2014). Consequently, reduced versions of STLS-R have been developed in the Netherlands- where a 19-item version has been validated (Overbeek, Ha, Scholte, de Kemp, \& Engels, 2007) -and Brazil where 15-item (Gouveia, Fonseca, Cavalcanti, Diniz, \& Dória, 2009); 16item (Cassepp-Borges \& Martins, 2009; Andrade, García, \& Cassepp-Borges, 2013) and 20-item (Cassepp-Borges \& Pasquali, 2014) versions have been developed.

In this context, and considering the current success of reduced STLS-R versions, the present study aims: (a) to translate a reduced Sternberg's Triangular Love Scale (STLS) from its original language (Portuguese) into Spanish; (b) to determine the factorial structure of STLS-R by using confirmatory factor analysis: (c) to estimate the reliability, using the internal consistency method, by means of the Omega coefficient: (d) to evaluate the factorial invariance (FI) across gender. In this regard, it is worth noting that, as far as we know, the FI of STLS-R as a function of gender has not been previously addressed. This fact naturally opens the question on whether or not the STLS-R items have the same meaning for men and women.

The relevance of this study relies on the fact that within the Peruvian framework, only a 45-item STLS (Ventura-León \& Caycho-Rodríguez, 2016) has been validated and it did not consider the structural equation approach. In addition, the validation of a reduced love scale in young and adult Peruvian couples certainly shed some light on the love phenomenon and its interrelation with other variables such as satisfaction (Lemieux \& Hale, 2000), sexual conduct (Martínez \& Rodas, 2008) or positive and negative emotions (Kim \& Hatfield, 2004). Furthermore, evaluating the FI of STLS-R has important implications for understanding love differences between men and women. Despite this fact, only few studies have addressed these differences between men and women, separately, using the STLS (Collins, Welsh, \& Furman, 1999; Ha, Overbeek, de Greef, Scholte, \& Engels, 2010; SeiffgeKrenke, 2003; Lemieux \& Hale, 2000), reporting that men demonstrate higher levels of passion, lower intimacy levels and similar levels of commitment with respect to women. However, such differences might not be significant (Gao, 2001; Ha et al., 2010) as the absence of FI evidence could lead to a misinterpretation of the findings associated with subgroup differences (Cheung \& Rensvold, 2002).

\section{Method}

\section{Participants}

The study was comprised of 988 Peruvian youth and adults, being 748 women and 240 men, whose ages ranged from 16 to 54 years $($ Mean $=21.26 ; S D=3.83)$, and who had been in a relationship for at least one month. The participants were either married, living with their partners, engaged, or dating. All the participants belonged to a middle social class in regard to socioeconomic status. In order to better control age variability, the participants were divided into three groups: From 16 to 19; from 20 to 21; and from 22 to 54 years. For further details, see table 1. For the factorial invariance analysis, 240 women were selected randomly from the total $(\mathrm{n}=988)$. This was done to equate the subgroups according to gender (Van de Schoot, Lugtig, \& Hox, 2012). 
Table 1

Sociodemographic features of participants

\begin{tabular}{lcc}
\hline \multicolumn{1}{c}{ Variables } & \multicolumn{2}{c}{ Total $(\mathrm{N}=988)$} \\
\hline Sex & & \\
Women & 748 & 75.7 \\
Men & 240 & 24.3 \\
Age (years) & & \\
16 a 19 & 313 & 31.7 \\
20 a 21 & 308 & 31.2 \\
22 a 54 & 367 & 37.1 \\
Relationship type & & \\
Married & 31 & 3.1 \\
Cohabiting & 34 & 3.4 \\
Dating & 839 & 85.0 \\
Engaged & 84 & 8.5 \\
Relationship duration (in months) & & \\
1 to 6 & 237 & 24.0 \\
7 to 33 & 495 & 50.1 \\
34 to 288 & 256 & 25.9 \\
\hline
\end{tabular}

Note. $f=$ Frequency

\section{Instrument}

A Portuguese version of the reduced Sternberg's love scale (STLS-R; Andrade, et al., 2013) was used. The scale was composed of 16 items with Likert-like alternatives going from $1=$ Never to $5=$ Always (see appendix A). The validity of the STLS-R was confirmed by exploratory and confirmatory factorial analysis indicating the presence of three factors that underlay the items, consistent with Sternberg's theory. The internal consistency reliability was estimated by using Cronbach's alpha coefficient which oscillates between .81 to .87 .

\section{Procedure}

For carrying out this work the ITC guidelines were followed ([International Test Commission, ITC], 2017). Initially, ethics approval for the current study was granted by the Board of Ethics of the Northern Private University. The translation-back translation approach was used to translate the STLS-R. That is to say, a non-affiliated bilingual person translated the scale from Portuguese to Spanish, while a second person translated the Spanish version back to Portuguese. Then the items were evaluated by the people who participated in the translation and the authors with the objective of resolving minor discrepancies and coming to a consensus on the translation. Next, the translated version was submitted to a pilot group with similar features to the final sample to ensure the comprehension of the items and prevent any kind of bias from arising due to linguistic issues, while at the same time being careful to maintain the semantic equivalence. For the sake of completeness, the original version and the Peruvian version of STLS-R is shown in Table 2.

The application of STLS-R was performed in two ways: (a) In person (60\%), where young and adult college students

Table 2

Original version in Portuguese and translation of the Peruvian version STLS-R

\begin{tabular}{|c|c|c|}
\hline Items* & Items of the original version in Portuguese & Translation of the items in Peruvian version \\
\hline $1(8)$ & Eu sinto que eu realmente entendo meu companheiro(a). & Siento que realmente comprendo a mi pareja. \\
\hline $2(12)$ & Tenho uma relação afetuosa com meu companheiro(a). & engo una relación afectuosa con mi pareja. \\
\hline $3(1)$ & $\begin{array}{l}\text { Espero que meu amor por meu companheiro(a) dure pelo resto da } \\
\text { vida. }\end{array}$ & $\begin{array}{l}\text { Espero que el amor que siento por mi pareja dure } \\
\text { jara toda la vida. }\end{array}$ \\
\hline $4(14)$ & Eu gosto muito do contato físico com meu companheiro(a). & Me gusta mucho el contacto físico con mi pareja \\
\hline $5(9)$ & o ativamente o bem estar de meu companheiro(a). & nente el bienestar de \\
\hline & nada atrapalhar meu & \\
\hline $7(6)$ & & con $\mathrm{n}$ \\
\hline $8(10)$ & Eu recebo muito apoio emocional de meu companheiro(a). & aucho apoyo emocional de \\
\hline $9(3)$ & Meu companheiro(a) pode contar comigo quando precisar. & 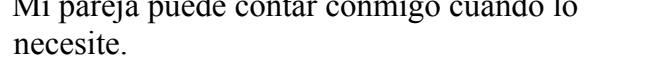 \\
\hline $10(4)$ & panheiro $(a)$ & Estoy segu \\
\hline 11(11) & to apoio emocional ao meu companheiro $($ a). & o apoyo emocional a mi pareja. \\
\hline $12(5)$ & $\begin{array}{l}\text { terminado a manter minha relação com meu } \\
\text { heiro }(a) \text {. }\end{array}$ & $\begin{array}{l}\text { Estoy decidido a mantener mi relación con mi } \\
\text { pareja. }\end{array}$ \\
\hline $13(6)$ & $\begin{array}{l}\text { Não deixaria que nada interferisse no meu compromisso com meu } \\
\text { companheiro }(a) \text {. }\end{array}$ & $\begin{array}{l}\text { No dejaría que nada se interfiera en mi compro- } \\
\text { miso con mi pareja. }\end{array}$ \\
\hline $14(15)$ & Eu acho meu companheiro(a) muito atraente. & Encuentro a mi pareja muy atractiva. \\
\hline $15(17)$ & $\begin{array}{l}\text { Me pego pensando em meu companheiro(a) várias vezes durante o } \\
\text { dia. }\end{array}$ & $\begin{array}{l}\text { Me quedo pensando en mi pareja varias veces al } \\
\text { día. }\end{array}$ \\
\hline $16(16)$ & Só em olhar para meu companheiro(a) fico excitado(a). & $\begin{array}{l}\text { Tan sólo con mirar a mi pareja me siento ex- } \\
\text { citado. }\end{array}$ \\
\hline
\end{tabular}

* The numbers in parentheses correspond to the original enumeration in Portuguese. 
were surveyed near the college facilities such as: rest areas, cafeterias, and gardens; (b) On-line (40\%), through on-line forms shared in social networks. These two forms of evaluation were established as a way to access a larger number of participants. For each one of the applications an informed consent was established by explaining conditions of anonymity, voluntary participation, confidentiality and veracity of information provided to the researcher.

\section{Data analysis}

The statistical analysis was carried out with the software "R" version 3.6.0 (R Development Core Team, 2019). Thus, the analysis was conducted in three steps: In the first stage, a descriptive statistical analysis including the mean, standard deviation, asymmetry and kurtosis was performed. In the second stage, the confirmatory factorial analysis (CFA) was chosen, instead of the exploratory factorial analysis (EFA), since the scale seeks to capture the Sternberg's theory features that are three-dimensionally defined. So, the technique should confirm the previous theoretical assumption (Arias, 2008). Thus, the CFA intended to provide evidence that only three factors best explain the subjects' responses, how the factors relate among them and how much the items loaded each factor (Lloret-Segura, Ferreres-Traver, HernándezBaeza, \& Tomás-Marco, 2014).

The CFA that was calculated through the library "lavaan" (Rosseelet al., 2018) was also carried out by using a polychoric correlation matrix as we are dealing with ordinal variables (Sanduvete-Chaves, Lozano-Lozano, Chacón-Moscoso, \& Holgado-Tello, 2018). In order to test the multivariate normality, the Mardia coefficient was calculated with a value $<70$ (Rodríguez \& Ruiz, 2008), which would indicate that it is necessary to test a robust estimator. Otherwise, an Unweighted Least Squares (ULS) estimator is preferred over the Weighted Least Square Mean and Variance Adjusted (WLSMV), as it is a valid option before ordinal variables (Jöreskog, 2003; DiStefano \& Morgan, 2014). The goodness-of-fit indices suggested by Mueller \& Hancock (2008) were reported: Rate between Chi-square and degree of freedom $[\chi 2 / \mathrm{df}]$ whose recommended values must be below 2 (Tabachnick \& Fidell, 2007), although higher values can be admitted (Wheaton, Muthen, Alwin, \& Summers, 1977); the root-mean-square error of approximation, RMSEA $<.06$ indicates the quality of adjustment; the standardized root mean residual, SRMR $<.08$ is optimal and finally, the comparative fit index CFI $\geq .95$ indicates a fair fit of the data (Browne \& Cudeck, 1993; Hu \& Bentler, 1999).

In light of the evidence provided about the internal structure of the study at first, it was proceeded to evaluate the FI of STLS-R on three levels (Byrne, 2008). Evaluating the configurational invariance this way implies checking whether the STLS-R scores are represented by the same amount of latent factors and free and fixed loading factors in both (Yap, et al, 2014); metric invariance, which suggests verifying if the factor loading is equal between groups (Hirschfeld, \& Von Brachel, 2014); strong invariance, which implies that the threshold is equivalent for both men and women (Schmitt \& Kuljanin, 2008). Additionally, the latent mean measurements were compared (Dimitrov, 2010).

The configurational invariance was checked with the $\mathrm{Hu}$ and Bentler (1999) criteria: CFI >.95; RMSEA $\leq .06$. For the comparison of the strong and metric invariance, it was taken as a reference that the differences between the CFI were below .010 in CFI; 0.15 in RMSEA; SRMR in .030 (Chen, 2007).

Finally, since the tau-equivalence was not satisfactory (Zinbarg, Revelle, Yovel, \& 2005) the reliability was estimated by means of the Omega coefficient $(\omega)$, which is recommended for factor models (McDonald, 1999).

\section{Results}

\section{Preliminary analysis of items}

In table 3, the central tendency and variability measures are presented. The mean reveals that item 9 ("My partner can count on me when he/she needs") presents the highest value while item 16 ("Just by looking at my partner I feel excited") presents lowest value. The standard deviation of items 3, 6, 15, 16 was the highest with values greater than one. On the other hand, all items have negative asymmetry that reveals a tendency towards higher scores. Accordingly, kurtosis of items 4, 5, 9, 10,11, 12 present a higher concentration of data around the center of its distribution.

Additionally, the Mardia coefficient whose value is equal to 41.13 is calculated; the same one that is lower than 70 , being unnecessary to attenuate the data, thus choosing an estimator like ULS instead of WLSMV.

\section{Confirmatory factor analysis (CFA)}

In order to verify the factor structure of the theoretical proposal, CFA is used. Therefore, a three-dimensional factor structure composed by 16 items was modeled. This model presents the following satisfactory goodness-of-fit parameters: $\left(\chi^{2}(101)=349.85 ; \chi 2 / \mathrm{df}=3.46 ; \mathrm{CFI}=.99\right.$; RMSEA $=.05[.04, .06]$; SRMR $=.05)$. The factor loading, and the inter-factor correlation are shown in Figure 1. 
Table 3

Preliminary item analysis $(N=988)$

\begin{tabular}{|c|c|c|c|c|}
\hline Items & $\mathrm{M}$ & $\sigma$ & g1 & g2 \\
\hline $\begin{array}{l}\text { 1. I feel like I really understand my partner. } \\
\text { [Siento que realmente comprendo a mi pareja.] }\end{array}$ & 3.62 & .865 & -0.45 & -0.02 \\
\hline $\begin{array}{l}\text { 2. I have an affectionate relationship with my partner. } \\
\text { [Tengo una relación afectuosa con mi pareja.] }\end{array}$ & 4.20 & .868 & -0.95 & 0.39 \\
\hline $\begin{array}{l}\text { 3. I hope my love for my partner persists for the rest of my life. } \\
\text { [Espero que el amor que siento por mi pareja dure para toda la vida.] }\end{array}$ & 4.01 & 1.095 & -0.86 & -0.15 \\
\hline $\begin{array}{l}\text { 4. I really like physical contact with my partner. } \\
\text { [Me gusta mucho el contacto físico con mi pareja.] }\end{array}$ & 4.33 & .865 & -1.41 & 1.99 \\
\hline $\begin{array}{l}\text { 5. I actively promote the well-being of my partner. } \\
\text { [Apoyo activamente el bienestar de mi pareja.] }\end{array}$ & 4.40 & .794 & -1.37 & 1.89 \\
\hline $\begin{array}{l}\text { 6. I have fantasies about my partner. } \\
\text { [Tengo fantasías con mi pareja.] }\end{array}$ & 3.82 & 1.182 & -0.74 & -0.44 \\
\hline $\begin{array}{l}\text { 7. I would not let anything ruin my commitment to my partner. } \\
\text { [No dejaría que nada obstaculice mi compromiso con mi pareja.] }\end{array}$ & 4.06 & .994 & -0.96 & 0.46 \\
\hline $\begin{array}{l}\text { 8. I receive a lot of emotional support from my partner. } \\
\text { [Recibo mucho apoyo emocional de mi pareja.] }\end{array}$ & 4.20 & .963 & -1.19 & 0.89 \\
\hline $\begin{array}{l}\text { 9. My partner can count on me when he/she needs. } \\
\text { [Mi pareja puede contar conmigo cuando lo necesite.] }\end{array}$ & 4.57 & .734 & -2.01 & 4.46 \\
\hline $\begin{array}{l}\text { 10. I am sure about my love for my partner. } \\
\text { [Estoy seguro de mi amor por mi pareja.] }\end{array}$ & 4.29 & .936 & -1.35 & 1.33 \\
\hline $\begin{array}{l}\text { 11. I give a lot of emotional support to my partner. } \\
\text { [Doy mucho apoyo emocional a mi pareja.] }\end{array}$ & 4.34 & .838 & -1.29 & 1.41 \\
\hline $\begin{array}{l}\text { 12. I am determined to maintain my relationship with my partner. } \\
\text { [Estoy decidido a mantener mi relación con mi pareja.] }\end{array}$ & 4.30 & .930 & -1.32 & 1.25 \\
\hline $\begin{array}{l}\text { 13. I would not let anything interfere on my commitment to my partner. } \\
\text { [No dejaría que nada se interfiera en mi compromiso con mi pareja.] }\end{array}$ & 4.14 & .980 & -1.07 & 0.65 \\
\hline $\begin{array}{l}\text { 14. I find my partner very attractive. } \\
\text { [Encuentro a mi pareja muy atractiva.] }\end{array}$ & 4.22 & .922 & -1.14 & 0.82 \\
\hline $\begin{array}{l}\text { 15. I catch myself thinking about my partner multiple times a day. } \\
\text { [Me quedo pensando en mi pareja varias veces al día.] }\end{array}$ & 3.90 & 1.068 & -0.71 & -0.25 \\
\hline $\begin{array}{l}\text { 16. Just by looking at my partner I feel excited. } \\
\text { [Tan solo con mirar a mi pareja me siento excitado.] }\end{array}$ & 3.16 & 1.203 & -0.07 & -0.88 \\
\hline
\end{tabular}

Note. $\mathrm{M}=$ Mean; $\sigma=$ Standard Deviation; $\mathrm{g} 1$ = Asymmetry; $\mathrm{g} 2=$ Kurtosis 


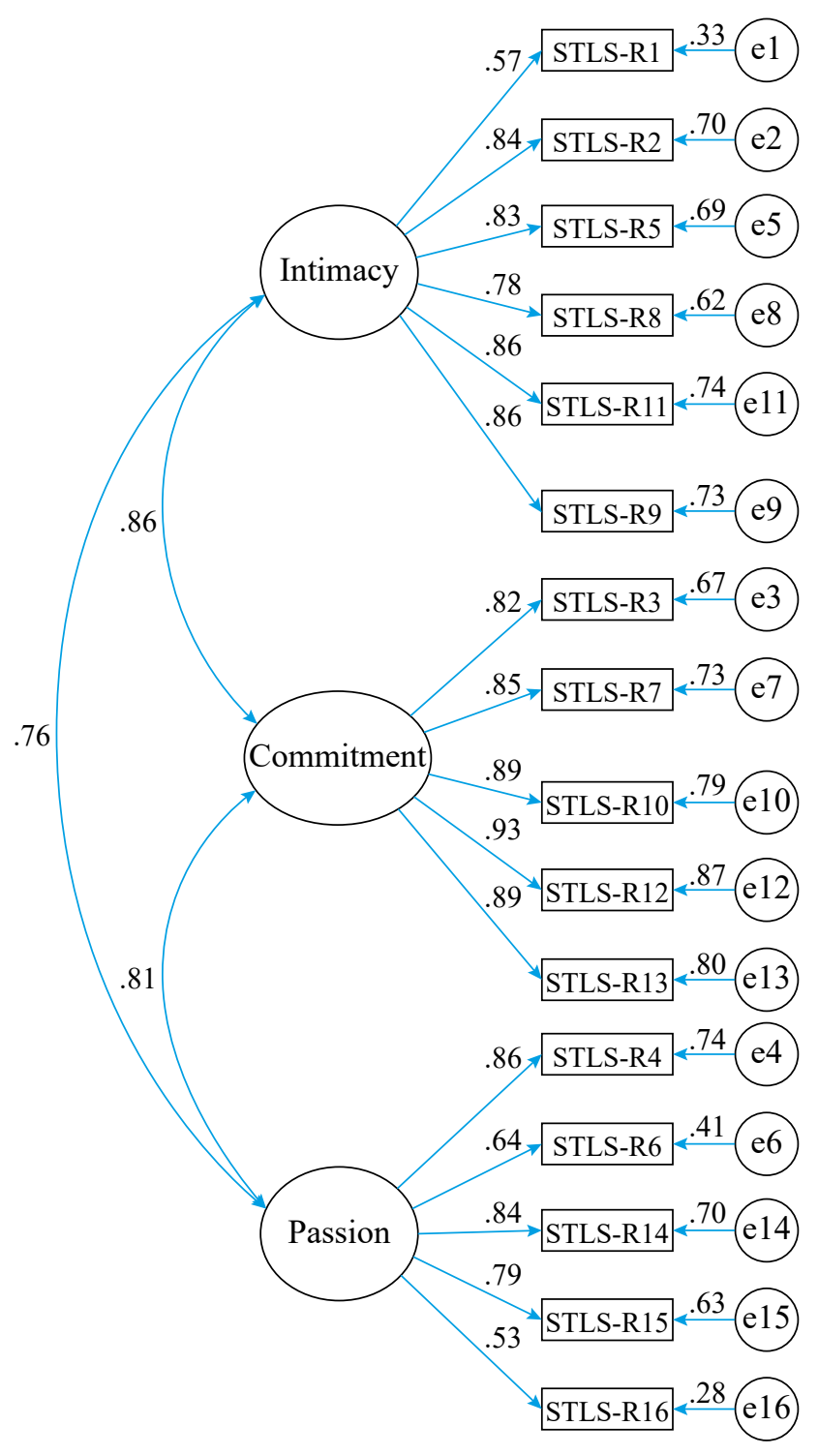

Figure 1. Factorial structure of STLS-R

\section{Invariance across gender}

Once the STLS-R factor structure was identified, the invariance across gender was progressively explored: configurational invariance (M1), metric invariance (M2), strong invariance (M3, Byrne, 2008). First, the model adjustment was examined without constraints in both subgroups (men and women) obtaining similar values. Subsequently, the STLS-R structure between subgroups (configurational invariance, M1) was analyzed, presenting optimal values, with $\chi_{(202)}^{2}=203.20$; CFI $=.1$; SRMR $=.050$ y RMSEA = $.004(.000, .025)$. These results indicate that M1 can be a referential model upon which one can set up constraints in models M2, M3, M4.

Moreover, the metric invariance (M2), defined as M1 with restrictions on the factor loading, was carried out,
Table 4

STLS-R factor matrix and reliability

\begin{tabular}{cccccc}
\hline Items & F1 & F2 & F3 & h2 & ritc \\
\hline 1 & .57 & & & .33 & .46 \\
2 & .84 & & & .70 & .68 \\
5 & .83 & & & .69 & .65 \\
8 & .78 & & & .62 & .62 \\
11 & .86 & & & .74 & .68 \\
9 & .86 & & & .73 & .63 \\
3 & & .82 & & .67 & .70 \\
7 & & .85 & & .73 & .71 \\
10 & & .89 & & .79 & .73 \\
12 & & .93 & & .87 & .77 \\
13 & & .89 & & .80 & .74 \\
4 & & & .86 & .74 & .67 \\
6 & & & .64 & .41 & .51 \\
14 & & & .84 & .70 & .66 \\
15 & & & .79 & .63 & .64 \\
16 & & & .53 & .28 & .44 \\
& & & & & \\
$\omega$ & .91 & .93 & .86 & & \\
Items & 6 & 5 & 5 & & \\
\hline
\end{tabular}

Note. F1: Intimacy; F2: Commitment; F3: Passion

finding the following appropriate indices: $\mathrm{CFI}=.999$ and RMSEA $=.020(.000, .032)$. It should be noted that the values between $\triangle \mathrm{CFI}$ are lower than the required cut-off point $(\Delta \mathrm{CFI}=.010$ y $\Delta \mathrm{RMSEA}=.015$; $\mathrm{SRMR}=.030$; Chen, 2007), which indicates the equivalence between the factor loading. Based on that, it is possible to compare the invariance of the covariances. Then, the equivalence between thresholds was verified (strong invariance, M3) where the difference between the CFI was below 0.010 (Chen, 2007). The above indicates that the thresholds are invariant, so it is possible to compare latent means between the subgroups (Dimitrov, 2010).

The latent factor means for each factor were estimated. With respect to intimacy, it is observed that women $(M=5.89)$ present a slightly higher value than men $(M=5.75)$; although the sample effect is negligible $(d=.15)$. Similarly, for the commitment factor, the means are almost the same for both groups $(M=5.15)$ and the sample effect can be neglected $(d=10)$. Finally, the mean for the passion factor of men $(M=4.37)$ was slightly higher than for women $(M=4.17)$ with a small sample effect $(d=.23)$. 
Table 5

STLS-R factor invariance $(N=240 *)$

\begin{tabular}{|c|c|c|c|c|c|c|c|c|}
\hline Model & $\begin{array}{c}\mathrm{x}^{2} \\
(\mathrm{df})\end{array}$ & $\begin{array}{l}\Delta \mathrm{x}^{2} \\
(\Delta \mathrm{df})\end{array}$ & $\begin{array}{l}\text { RMSEA } \\
\text { [IC } 90 \%]\end{array}$ & SRMR & CFI & $\Delta \mathrm{CFI}$ & $\triangle \mathrm{RMSEA}$ & $\Delta \mathrm{SRMR}$ \\
\hline Women & $\begin{array}{c}110.827 \\
(101)\end{array}$ & - & $\begin{array}{c}.018 \\
{[.000, .036]}\end{array}$ & .050 & .999 & - & - & - \\
\hline Men & $\begin{array}{c}92.369 \\
(101)\end{array}$ & - & $\begin{array}{c}.00 \\
{[.000, .024]}\end{array}$ & .045 & 1 & - & - & - \\
\hline M1 & $\begin{array}{c}203.20 \\
(202)\end{array}$ & - & $\begin{array}{c}.004 \\
{[.000, .025]}\end{array}$ & .050 & 1 & - & - & - \\
\hline M2 & $\begin{array}{c}239.28 \\
(215)\end{array}$ & $36.086(13)$ & $\begin{array}{c}.020 \\
{[.000, .032]}\end{array}$ & .052 & .999 & .001 & .015 & .002 \\
\hline M3 & $\begin{array}{c}339.08 \\
(260)\end{array}$ & $99.800(45)$ & $\begin{array}{c}.032 \\
{[.022, .041]}\end{array}$ & .053 & .997 & .002 & .013 & .001 \\
\hline M4 & $\begin{array}{c}396.81 \\
(276)\end{array}$ & $57.729(16)$ & $\begin{array}{c}.038 \\
{[.030, .047]}\end{array}$ & .054 & .995 & .005 & .016 & .001 \\
\hline
\end{tabular}

Note. M1: Configurational; M2: Metric; M3: Strong; M4: Strict; *: quantity per each group.

\section{Reliability}

The values for omega coefficient $(\omega)$ were above .85 for the three factors: intimacy $(\omega=.91)$, commitment $(\omega$ $=.93)$ and passion $(\omega=.86)$.

\section{Discussion}

This study aimed to explore the internal structure, reliability and factor invariance according to sex of the STLS-R for Peruvian youth and adults. The results of CFA confirmed that the three-dimensional model shows satisfactory goodness-of-fit indices. This result is in line with previous reports in Latin America (i.e., Andrade, et al., 2013; Cassepp-Borges \& Martins, 2009; Cassepp-Borges \& Pasquali, 2014; Gouveia, et al., 2009), even though different versions of STLS-R had been used. A deeper discussion of main findings will be presented in detail as follows:

Regarding the reliability of the $\omega$ coefficient, it was above .85 for all dimensions, where the passion factor presented the lowest value $(\omega=.86)$. This is consistent with previous studies (Cassepp-Borges \& Pasquali, 2014; Cassepp-Borges \& Teodoro, 2007; Cassepp-Borges y Pasquali, 2012; Hernández, 1999; Andrade, et al., 2013). The coefficient $\omega$ was chosen since it is considered adequate when factor analysis is used (Mcdonald, 1999).

On the other hand, the results show the presence of factor invariance with respect to gender. The presence of configurational invariance implies that the three-factor model is valid for men and women. In this regard, from a psychological perspective, both genders present the same components of love when answering the STLS-R. With respect to the metric invariance, these results indicate that the factor loading is equal between the groups (Lievens, Anseel, Harris, \& Eisenberg, 2007). From this, it can be inferred that both men and women give the same relative importance to all the items. The presence of strong invariance indicates that people might obtain similar love scores regardless their gender. Finally, the achievement of strict invariance proves the equivalence in the items' error variation for both groups (Millsap \& Kwok, 2004).

Since it was possible to demonstrate the strong invariance, it was proceeded to estimate the latent means (Dimitrov, 2010) which reveals that women are more intimate while men are more passionate; but its size of effect is considered negligible. This aligns with previous studies (Ahmetoglu, Swami, \& Chamorro-Premuzic, 2009; Sumter, Valkenburg, \& Peter, 2013) and highlights that the observed differences in love, between men and women, can be attributed to differences between groups (Schmitt \& Kuljanin, 2008).

It should be noted that besides the solid methodology and theoretical basis, the present study has some limitations. First, by including only youth or adults in the sample, the possible generational differences could be suppressed which may have somehow biased the overall results and limited the ecological validity, a situation that must be addressed in further studies.

In this sense, the FI of STLS-R can be investigated in different age groups to ensure whether the items of STLS-R have different meaning for men and women of different age ranges. In the sample studied, there is a substantial difference between the group of men and women. Indeed, such explored differences according to sex, must be considered with caution. Furthermore, it is 
advisable that future research guarantee the equivalence across groups. Secondly, the participants are from Lima, Peru, so one should expect that the findings might not be representative of the general Peruvian population of youth and adults. Additionally, there is a considerable difference in the numbers of men and women that can be monitored in future studies. Third, the present study does not provide information on the evidence of convergent and discriminant validity of STLS-R. This suggests that further studies are necessary in order to determine how different STLS-R is from other love measurements. Finally, test-retest and longitudinal FI reliability was not tested.

In summary, it was confirmed that the three-dimensional structure of STLS-R offers satisfactory goodness-of-fit indices to compare men and women. Therefore, STLS-R appears to be a valid and precise instrument to measure love in youth and adults from Lima, Peru. Based on these results, it is important to continue evaluating other sources of variation (for example, culture or age) that are important to achieve a deep understanding of love in Peruvian youth and adults of both genders. To this aim, the limitations described in this study must be taken into account. Therefore, the STLS-R has a clear advantage over other versions of the STLS due to its smaller number of items, which can be valuable for future investigations on romantic relationships.

\section{References}

Ahmetoglu, G., Swami, V., \& Chamorro-Premuzic, T. (2009). The Relationship Between Dimensions of Love, Personality, and Relationship Length. Archives of Sexual Behavior, 39(5), 1181-1190. doi:10.1007/s10508-009-9515-5.

Al-Krenawi, A., \& Jackson, S. O. (2014). Arab American marriage: Culture, tradition, religion, and the social worker. Journal of Human Behavior in the Social Environment, 24(2), 115-137. doi:10.1080/10911359.2014.848679

Andrade, A. L., Garcia, A., \& Cassepp-Borges, V. (2013). Evidências de validade da escala triangular do amor de Sternberg-reduzida (ETAS-R). Psico-USF, 18(3), 501-510. doi:10.1590/S1413-82712013000300016

Browne, M. W., \& Cudeck, R. (1993). Alternative ways of assessing model fit. En K. A. Bollen \& J. S. Long (Eds.), testing structural equation models (pp. 136-162). Newbury Park, CA: Sage.

Byrne, B. M. (2008). Testing for multigroup equivalence of a measuring instrument: A walk through the process. Psicothema, 20(4), 872-882. Recuperado de http://www. psicothema.com/PDF/3569.pdf

Cassepp-Borges, V. \& Martins, M. (2009). Versión Reducida de la Escala Triangular del Amor: Características del
Sentimiento en Brasil. Revista Interamericana de Psicología, 43 (1), 30-38.

Cassepp-Borges, V., \& Pasquali, L. (2012). Estudo nacional dos atributos psicométricos da Escala Triangular do Amor de Sternberg. Paidéia, 22(51). 21-31. doi:10.1590/ S0103-863X2012000100004

Cassepp-Borges, V., \& Pasquali, L. (2014). A redução de itens como uma alternativa para a Escala Triangular do Amor. Psicologia, 28(2), 11-20. Recuperado de http://www.scielo.mec.pt/scielo. php?script=sci_arttext\&pid=S0874-20492014000200002

Cassepp-Borges, V., \& Teodoro, M. L. (2007). Propriedades psicométricas da versão brasileira da Escala Triangular do Amor de Sternberg. Psicologia: Reflexão e Crítica, 20(3), 513-522. doi:10.1590/S0102-79722007000300020

Chen, F. F. (2007). Sensitivity of goodness of fit indexes to lack of measurement invariance. Structural Equation Modeling: A Multidisciplinary Journal, 14(3), 464-504.

Cheung, G. W., \& Rensvold, R. B. (2002). Evaluating goodness-of-fit indexes for testing measurement invariance. Structural equation modeling, 9(2), 233-255. doi:10.1207/ S15328007SEM0902_5

Collins, W. A., Welsh, D. P., \& Furman, W. (2009). Adolescent romantic relationships. Annual Review of Psychology, 60, 631-652. doi:10.1146/annurev.psych.60.110707.163459.

De Zubiría, M. (2002). ¿Qué es el amor? Bogotá: Fondo de Publicaciones Bernardo Herrera Merino.

Díaz-Loving, R., \& Sánchez, A. (2002). Psicología del amor: una visión integral de la relación de pareja. México: Universidad Nacional Autónoma de México.

Diessner, R., Frost, N., \& Smith, T. (2004). Describing the neoclassical psyche embedded in Sternberg's triangular theory of love. Social Behavior and Personality: an international journal, 32(7), 683-690. doi:10.2224/sbp.2004.32.7.683

Dimitrov, D. M. (2010). Testing for factorial invariance in the context of construct validation. Measurement and Evaluation in Counseling and Development, 43(2), 121149. doi: $10.1177 / 0748175610373459$

DiStefano, C., \& Morgan, G. B. (2014). A comparison of diagonal weighted least squares robust estimation techniques for ordinal data. Structural Equation Modeling: $A$ Multidisciplinary Journal, 21(3), 425-438. doi:10.1080/10 705511.2014.915373

Evangelho, J. A. (2016). Análise fatorial exploratória e hierárquica da Escala Triangular do Amor. Avaliação Psicológica, 15(1),11-20. Recuperadodehttp://pepsic.bvsalud.org/scielo. php?script=sci_arttext\&pid=S1677-04712016000100003

Frankl, V. (1997). Psicoanálisis y existencialismo. De la psicoterapia a la logoterapia. México: Fondo de cultura económica.

Freud, S. (1922). Certain neurotic mechanisms in jealousy, paranoia and homosexuality (J. Riviere, Trans.). In P. Reif 
(Ed.), Sexuality and the psychology of love (pp. 123-149). New York, NY: Simon \& Schuster Inc.

Fromm, E. (2004). El arte de amar. Buenos Aires: Paidós.

Gao, G. (2001). Intimacy, passion, and commitment in Chinese and US American romantic relationships. International Journal of Intercultural Relations, 25(3), 329-342. doi:10.1016/S0147-1767(01)00007-4

Gouveia, V. V., Fonseca, P. D., Cavalcanti, J. P. N., Diniz, P. D. C., \& Dória, L. C. (2009). Versão abreviada da Escala Triangular do Amor: Evidências de validade fatorial e consistência interna. Estudos de Psicologia, 14(1), 31-39. doi:10.1590/S1413-294X2009000100005

Graham,J.M.(2011). Measuring lovein romantic relationships:A meta-analysis. Journal of Social and Personal Relationships, 28(6), 748-771. doi:10.1177/0265407510389126

Ha, T., Overbeek, G., de Greef, M., Scholte, R. H. J., \& Engels, R. C. M.E. (2010). The importance of relationships with parents and best friends for adolescents' romantic relationship quality: Differences between indigenous and ethnic Dutch adolescents. International Journal of Behavioral Development, 34(2), 121-127. doi:10.1177/0165025409360293.

Hatfield, E., \& Rapson, R. L. (1996). Stress and passionate love. Stress and emotion: Anxiety, anger, and curiosity, 16, 29-50. Recuperado de http://www.elainehatfield.com/ uploads/3/4/5/2/34523593/57._hatfield_rapson_1996.pdf

Hatfield, E., Bensman, L., \& Rapson, R. L. (2012). A brief history of social scientists' attempts to measure passionate love. Journal of Social and Personal Relationships, 29(2), 143-164. doi:10.1177/0265407511431055

Hatfield, E., Rapson, R. L., \& Martel, L. (2007). Passionate love and sexual desire. In S. Kitayama \& D. Cohen (Eds.). Handbook of cultural psychology (pp. 760-779). New York: Guilford Press.

Heinrich, D., Albrecht, C. M., \& Bauer, H. H. (2012). Love actually? Measuring and exploring consumers' brand love. Consumer-Brand Relationships-Theory and Practice. London: Routledge.

Hernández, J. A. E. (1999). Validação da Estructura da Escala Triangular do Amor: Análise fatorial confirmatória. Aletheia, 9, 15-25

Hirschfeld, G., \& Von Brachel, R. (2014). Multiple-Group confirmatory factor analysis in R-A tutorial in measurement invariance with continuous and ordinal indicators. Practical Assessment, Research \& Evaluation, 19(7), 1-12.

Hu, L. T., \& Bentler, P. M. (1999). Cutoff criteria for fit indexes in covariance structure analysis: Conventional criteria versus new alternatives. Structural equation modeling: a multidisciplinary journal, 6(1), 1-55. doi:10.1080/10705519909540118

International Test Commission (2017). The ITC Guidelines for Translating and Adapting Tests (Second edition). [www. InTestCom.org]
Jöreskog, K. G. (2003). Factor Analysis by MINRES. To the Memory of Harry Harman and Henry Kaiser. Disponible en http://www.ssicentral.com/lisrel/techdocs/minres.pdf

Kim, J., \& Hatfield, E. (2004). Love types and subjective wellbeing. Social Behavior and Personality: An International Journal, 32, 173-182. doi:10.2224/sbp.2004.32.2.173

Le Breton, D. (1999). Cuerpo y comunicación. Las pasiones ordinarias. Antropología de las emociones. Buenos Aires: Nueva Visión.

Lee, J. A. (1977). A typology of styles of loving. Personality and Social Psychology Bulletin, 3(2), 173-182. doi:10.1177/014616727700300204

Lemieux, R., \& Hale, J. L. (2000). Intimacy, passion and commitment among married individuals: Further testing of the triangular theory of love. Psychological Reports, 87, 941948. doi:10.2466/pr0.2000.87.3.941

Levin, J., \& Kaplan, B. H. (2010). The Sorokin Multidimensional Inventory of Love Experience (SMILE): development, validation, and religious determinants. Review of Religious Research, 51(4), 380-401. doi:10.2307/20778530

Lievens, F., Anseel, F., Harris, M. M., \& Eisenberg, J. (2007). Measurement invariance of the Pay Satisfaction Questionnaire across three countries. Educational and Psychological Measurement, 67(6), 1042-1051. doi:10.1177/0013164406299127

Martinez, L., \& Rodas, S. (2008). Relación entre estilos de amor y satisfacción sexual en hombres de 22 y 47 años. Eureka, 8(2), 267-277. Recuperado de http://pepsic.bvsalud.org/scielo.php?script=sci_arttext\&pid $=\mathrm{S} 2220-90262011000200011$

Maslow, A. H. (1991). Motivación y personalidad. Madrid: Ediciones Díaz de Santos.

Mazadiego, T., \& Norberto, J. (2011). El amor medido por la escala triangular de Sternberg. Psicolatina, 22, 1-10. Recuperado de http://psicolatina.org/22/seccion1/amor.pdf

McDonald, R. P. (1999). Test theory: A unified treatment. Mahwah, NJ: Erlbaum.

Millsap, R. E., \& Kwok, O. (2004). Evaluating the impact of partial factorial invariance on selection in two populations. Psychological Methods, 9(1), 93-115. doi:10.1037/1082-989X.9.1.93

Mueller, R. O., \& Hancock, G. R. (2008). Best practices in structural equation modeling. In J. W. Osborne (Ed.). Best practices in quantitative methods (pp. 488-508). Thousand Oaks, CA: Sage

Neto, F., \& da Conceição Pinto, M. (2015). Satisfaction with love life across the adult life span. Applied Research in Quality of Life, 10(2), 289-304. doi:10.1007/s11482-014-9314-6

Ortega y Gasset, J. (1939/2005). Estudios sobre amor. Madrid: Editorial Edaf.

Overbeek, G., Ha, T., Scholte, R., de Kemp, R., \& Engels, R. C. (2007). Brief report: Intimacy, passion, and commitment in romantic relationships-Validation of a 'triangular love 
scale'for adolescents. Journal of adolescence, 30(3), 523528. doi:10.1016/j.adolescence.2006.12.002

Pilishvili T. S., \& Koyanongo E. (2016). The representation of love among Brazilians, Russians and Central Africans: A comparative analysis. Psychology in Russia: State of the Art, 9(1), 84-97.

Precht, R. D. (2012). Amor: un sentimiento desordenado. Madrid: Siruela.

R Development Core Team (2019). R: A language and environment for statistical computing. Viena, Austria: R Foundation for Statistical Computing [programa informático] [en línea] Disponible en https://cran.r-project.org/

Rodríguez, M. N., \& Ruiz, M. A. (2008). Atenuación de la asimetría y de la curtosis de las puntuaciones observadas mediante transformaciones de variables: Incidencia sobre la estructura factorial. Psicológica, 29(2), 205-27. Recuperado de http://www.redalyc.org/html/169/16929206/

Rosseel, Y., Oberski, D., Byrnes, J., Vanbrabant, L., Savalei, V., Merkle, E., ... \& Chow, M. (2018). Package 'lavaan'. Recuperado el 03 de enero2018 de https://pdfs.semanticscholar.org/e465/add515cdeeaa8de57bd1a9adc2569e44fa9a.pdf

Rubin, Z. (1970). Measurement of romantic love. Journal of Personality and Social Psychology, 16, 265-273. doi:10.1037/h0029841

Sakuray, P., \& Akemi, C. (2014). Relaciones amorosas en descendientes japoneses. Ajayu Órgano de Difusión Científica del Departamento de Psicología UCBSP, 12(2), 207-226.

Sanduvete-Chaves, S., Lozano-Lozano, J. A., Chacón-Moscoso, S., \& Holgado-Tello, F. P. (2018). Development of a Work Climate Scale in Emergency Health Services. Frontiers in psychology, 9, 10. doi:10.3389/fpsyg.2018.00010

Schmitt, N., \& Kuljanin, G. (2008). Measurement invariance: Review of practice and implications. Human Resource Management Review, 18, 210 -222. doi:10.1016/j. hrmr.2008.03.003

Scott, M. (1997). La nueva psicología del amor. Buenos Aires: Emecé Editores.

Seiffge-Krenke, I. (2003). Testing theories of romantic development from adolescence to young adulthood: Evidence of a developmental sequence. International Journal of Behavioral Development, 27(6), 519-531. doi:10.1080/01650250344000145

Singer, I. (2006). La naturaleza del amor (4 ed.). México D.F.: Siglo XXI.

Sternberg, R. J.(1986). A triangular theory of love. Psychological Review, 93, 119-135. doi:10.1037/0033-295X.93.2.119
Sternberg, R. J. (1997). Construct validation of a triangular love scale. European Journal of Psychology, 27, 313-335. doi:10.1002/(SICI)1099-0992(199705)27:3<313:AIDEJSP824>3.0.CO;2-4

Sternberg, R. J., \& Barnes, M. L. (1988). The psychology of love. New Haven: Yale University

Sumter, S. R., Valkenburg, P. M., \& Peter, J. (2013). Perceptions of love across the lifespan. Differences in passion, intimacy, and commitment. International Journal of Behavioral Development, 37(5), 417-427. doi:10.1177/0165025413492486.

Tabachnick, B. G., \& Fidell, L. S. (2007). Using multivariate statistics. Allyn \& Bacon/Pearson Education.

Van de Schoot, R., Lugtig, P., \& Hox, J. (2012). A checklist for testing measurement invariance. European Journal of Developmental Psychology, 9(4), 486-492. doi:10.1080/17 405629.2012.686740

Ventura-León, J. L., \& Caycho-Rodríguez, T. (2016). Análisis exploratorio de la escala de amor de Sternberg en estudiantes universitarios peruanos. Acta de Investigación Psicológica-Psychological Research Records, 6(2), 24302439. doi:10.1016/j.aipprr.2016.06.006

Vera, G. (2017). Love in cross-cultural perspective: Mozambique-France comparison. Journal of Psychology in Africa, 27(4), 334-337. doi:10.1080/14330237.2017.13477 54

Wan Shahrazad, W. S., Hoesni, S. M., \& Chong, S. T. (2012). Investigating the factor structure of the Love Attitude Scale (LAS) with Malaysian samples. Asian Social Science, 8(9), 66-73. doi:10.5539/ass.v8n9p66

Wheaton, B., Muthen, B., Alwin, D. F., \& Summers, G. F. (1977). Assessing reliability and stability in panel models. Sociological methodology, 8, 84-136. doi:10.2307/270754

Whitley, B. E. (1993). Reliability and aspects of the construct validity of Sternberg's Triangular Love Scale. Journal of Social and Personal Relationships, 10(3), 475-480. doi:10.1177/0265407593103013

Yap, S. C., Donnellan, M. B., Schwartz, S. J., Kim, S. Y., Castillo, L. G., Zamboanga, B. L., ... \& Vazsonyi, A. T. (2014). Investigating the structure and measurement invariance of the Multigroup Ethnic Identity Measure in a multiethnic sample of college students. Journal of Counseling Psychology, 61(3), 437. doi:10.1037/a0036253

Zinbarg, R. E., Revelle, W., Yovel, I., \& Li, W. (2005). Cronbach's $\alpha$, Revelle's $\beta$, and McDonald's $\omega$ H: Their relations with each other and two alternative conceptualizations of reliability. Psychometrika, 70(1), 123-133. doi:10.1007/ s11336-003-0974-7 


\section{Appendix A}

\section{STLS-R}

Instrucciones: A continuación se le presenta un conjunto de preguntas acerca de su relación de pareja. Responda las preguntas valorando en una escala del 1 al 5, donde:

$\begin{array}{ccccc}1 & 2 & 3 & 4 & 5 \\ \text { Nunca } & \text { A veces } & \text { Confrecuencia } & \text { Muchísimas veces } & \text { Siempre }\end{array}$

\section{Preguntas}

1. Siento que realmente comprendo a mi pareja.

2. Tengo una relación afectuosa con mi pareja.

3. Espero que el amor que siento por mi pareja dure para toda la vida.

4. Me gusta mucho el contacto físico con mi pareja.

5. Apoyo activamente el bienestar de mi pareja.

6. Tengo fantasías con mi pareja.

7. No dejaría que nada obstaculice mi compromiso con mi pareja.

8. Recibo mucho apoyo emocional de mi pareja.

9. Mi pareja puede contar conmigo cuando lo necesite.

10. Estoy seguro de mi amor por mi pareja.

11. Doy mucho apoyo emocional a mi pareja.

12. Estoy decidido a mantener mi relación con mi pareja.

13. No dejaría que nada se interfiera en mi compromiso con mi pareja.

14. Encuentro a mi pareja muy atractiva.

15. Me quedo pensando en mi pareja varias veces al día.

16. Tan solo con mirar a mi pareja me siento excitado.

$\begin{array}{lllll}1 & 2 & 3 & 4 & 5 \\ 1 & 2 & 3 & 4 & 5 \\ 1 & 2 & 3 & 4 & 5 \\ 1 & 2 & 3 & 4 & 5 \\ 1 & 2 & 3 & 4 & 5 \\ 1 & 2 & 3 & 4 & 5 \\ 1 & 2 & 3 & 4 & 5 \\ 1 & 2 & 3 & 4 & 5 \\ 1 & 2 & 3 & 4 & 5 \\ 1 & 2 & 3 & 4 & 5 \\ 1 & 2 & 3 & 4 & 5 \\ 1 & 2 & 3 & 4 & 5 \\ 1 & 2 & 3 & 4 & 5 \\ 1 & 2 & 3 & 4 & 5 \\ 1 & 2 & 3 & 4 & 5 \\ 1 & 2 & 3 & 4 & 5\end{array}$

